\title{
MODEL PEMBELAJARAN INOVATIF BERBASIS KONSEP SEKOLAH RAMAH ANAK Encep Sudirjo
}

\begin{abstract}
Abstrak
Anak yang belajar dengan dimensi sekolah ramah anak selain anak merasa senang, potensinya tergali dan terkembangkan. Dengan model pembelajaran yang lebih mengutamakan aktifitas siswa, sekolah juga menyediakan lingkungan dan fasilitas yang mengakomodir apa yang diinginkan siswa sehingga siswa menjadi senang belajarnya. Siswa dilibatkan dalam berbagai aktifitas yang dapat mengembangkan kemampuannya (learning by doing). Siswa diberi kesempatan untuk menyampaikan gagasannya, memajangkan hasil karyanya diikutsertakan dalam pemeliharaan fasilitas sekolah. Dengan memperhatikan hal-hal tersebut akan memungkinkan menghasilkan lulusan yang berkualitas. Dengan demikian untuk tercapainya kualitas lulusan, pendidikan tidak harus dilakukan dengan kekerasan. Malahan kekerasan dapat menghambat bahkan hilangnya potensi yang dimiliki anak. Jadi betapa pentingnya sekolah ramah anak dimunculkan dalam pengembangan pendidikan dasar.
\end{abstract}

\section{Kata Kunci: Model Pembelajaran Inovatif, Sekolah Ramah Anak}

\section{A. Pendahuluan}

Perubahan Kurikulum lama menjadi Kurikulum 2004 berbasis kompetensi (KBK), yang diperbaharui dengan Kurikulum 2006 (KTSP), telah berlaku selama 4 tahun dan semestinya dilaksanakan secara utuh pada setiap sekolah. Namun kenyataannya, dalam pelaksanaan pembelajaran di sekolah, masih kurang memperhatikan ketercapaian kompetensi siswa. Hal ini tampak pada rencana pembelajaran yang dibuat oleh guru juga dari cara guru mengajar di kelas masih tetap menggunakan cara lama. Pembelajaran masih dominan menggunakan metode ceramah-ekspositori. Guru masih dominan dan siswa resisten, guru masih menjadi pemain dan siswa penonton, guru aktif dan siswa pasif. Paradigma lama masih melekat karena kebiasaan yang susah diubah. Paradigma mengajar masih tetap dipertahankan dan belum berubah menjadi peradigma membelajarkan siswa. Padahal, tuntutan KBK, pada penyusunan RPP menggunakan istilah skenario pembelajaran untuk pelaksanaan pembelajaran di kelas. Ini mengandung arti bahwa guru sebagai sutradara dan siswa menjadi pemain, jadi guru memfasilitasi aktivitas siswa dalam mengembangkan kompetensinya sehingga memiliki kecakapan hidup (life skill) untuk bekal hidup dan penghidupannya sebagai insan mandiri. Demikian pula, pada pihak siswa, karena kebiasaan menjadi penonton dalam kelas, mereka sudah merasa enjoy dengan kondisi menerima dan tidak 
biasa memberi. Selain karena kebiasaan yang sudah melekat mendarah daging dan sukar diubah. Kondisi ini kemungkinan disebabkan pengetahuan guru yang masih terbatas tentang bagaimana siswa belajar dan bagaimana cara membelajarkan siswa.

Terbitnya PP No. 19/2005 tentang Standar Nasional Pendidikan, UU No. 14/2005 tentang Guru dan Dosen, dan PP No. 74/2008 tentang Guru, maka kompetensi guru yang diharapkan menyangkut kompetensi kepribadian, paedagogik, keprofesionalan dan sosial. Dengan kompetensi itu diharapkan kinerja guru mengalami perubahan-perubahan yang inovatif. Diharapkan dampak yang paling utama pada proses pembelajaran, sehingga akan merubah mutu lulusan.

Apalagi dengan terbitnya UU No. 23/ 2002 tentang perlindungan anak, khususnya perlindungan anak di dalam institusi pendidikan, ditindaklanjuti dengan dibangunnya kerjasama antara Kementrian Negara Pemberdayaan Perempuan (KPP) dengan Departemen Pendidikan Nasional untuk merumuskan model sekolah ramah anak dengan tujuan untuk membangun pendidikan tanpa menggunakan kekerasan. Tidak hanya kekerasan yang dilakukan sekolah terhadap anak tetapi juga kekerasan yang terjadi antara anak dengan anak. Padahal Dorothy Low Noite dalam Children Learn What They Live With” mengatakan Jika anak dikerumuni keramahan, ia akan terbiasa berpendirian

Kenyataan dalam dunia pendidikan telah terjadi kekerasan baik yang dilakukan oleh orang dewasa dalam hal ini guru maupun antara anak dengan anak. Bahkan kerap kali didengar tentang tawuran antar sekolah, tawuran antar masyarakat. Contohnya dikemukakan oleh Saptandari (2007: 8) yang mengemukakan kematian Edo, siswa kelas II SD Santa Maria Immaculata Jakarta Timur, pada akhir 2007 merupakan signal bagi seluruh masyarakat dimana perlindungan anak di sekolah harus lebih ditingkatkan sebagai implementasi UU Perlindungan Anak. Ternyata kekerasan itu tidak hanya muncul di pendidikan dasar saja bahkan sampai ke Perguruan Tinggi. Apakah ini hasil pendidikan atau hanya ekses lain dari oknum pendidikan.

Memperhatikan masalah di atas nyatalah betapa pentingnya pendidikan yang berlandaskan keramahan dengan tidak melupakan peningkatan disiplin dan pengembangan potensi yang dimilki anak. Betapa pentingnya model pembelajaran yang dapat mengembangkan potensi yang dimiliki anak dengan menggunakan pembelajaran yang ramah anak. Model pembelajaran seperti itu harus dimiliki oleh setiap pendidik, baik dalam pendidikan informal, formal maupun non formal. Paling tidak untuk menghasilkan pendidik seperti itu merupakan tugas Lembaga Pendidikan Tenaga Kependidikan. Oleh karena itu, Lembaga Pendidikan Tenaga 
Kependidikan (LPTK), harus mampu menghasilkan guru profesional yang menguasai baik soft skills maupun hard skills, berperan serta dalam meningkatkan mutu pendidikan nasional, memiliki landasan kapasitas berupa karakter yang kuat, serta menghargai keragaman sebagai perekat integrasi bangsa.

\section{B. Pembahasan}

Dalam pembahasan ini akan dikaji tentang konsep-konsep pembelajaran, pembelajaran yang inovatif, model sekolah ramah anak dan bagaimana pembelajaran pada sekolah ramah anak.

\section{Model Pembelajaran dan Pengembangannya}

Pembelajaran adalah proses interaksi peserta didik dengan pendidik dan sumber belajar pada suatu lingkungan belajar. Pembelajaran merupakan bantuan yang diberikan pendidik agar dapat terjadi proses pemerolehan ilmu dan pengetahuan, penguasaan kemahiran dan tabiat, serta pembentukan sikap dan kepercayaan pada peserta didik. Dengan kata lain, pembelajaran adalah proses untuk membantu peserta didik agar dapat belajar dengan baik. Proses pembelajaran dialami sepanjang hayat seorang manusia serta dapat berlaku di manapun dan kapanpun. Pembelajaran mempunyai pengertian yang mirip dengan pengajaran, walaupun mempunyai konotasi yang berbeda. Dalam konteks pendidikan, guru mengajar supaya peserta didik dapat belajar dan menguasai isi pelajaran hingga mencapai sesuatu objektif yang ditentukan (aspek kognitif), juga dapat mempengaruhi perubahan sikap (aspek afektif), serta keterampilan (aspek psikomotor) seseorang peserta didik. Pengajaran memberi kesan hanya sebagai pekerjaan satu pihak, yaitu pekerjaan guru saja. Sedangkan pembelajaran juga mengisaratkan adanya interaksi antara guru dengan peserta didik.

Weinstein \& Meyer (1998) mengemukakan bahwa dalam pembelajaran harus memperhatikan empat hal, yaitu bagaimana siswa belajar, mengingat, berpikir, dan memotivasi diri. Dalam belajar apapun, belajar efektif (sesuai tujuan) semestinya bermakna. Agar bermakna, belajar tidak cukup dengan hanya mendengar dan melihat tetapi harus dengan melakukan aktivitas (membaca, bertanya, menjawab, berkomentar, mengerjakan, mengkomunikasikan, presentasi, diskusi). Dalam bahasa Sunda ada pepatah pok-pek-prak; yang berarti bahwa belajar mempunya indikator berkata-pok (bertanya-menjawab-diskusi, presentasi). Mencoba-pek (menyelidiki, meng-identifikasi, menduga, menyimpulkan, menemukan), dan melaksanakan-prak (mengaplikasikan, menggunakan, memanfaatkan, mengembangkan). Tokoh pendidikan nasional Ki Hajar Dewantoro (1908) mengemukakan tiga prinsip pembelajaran ing ngarso sung tulodo (jadi pemimpin-guru jadilah teladan bagi siswanya), ing madyo mangun karso (dalam pembelajaran membangun ide siswa dengan aktivitas sehingga 
kompetensi siswa terbentuk), tut wuri handayani (jadilah fasilitator kegiatan siswa dalam mengembangkan life skill sehingga mereka menjadi pribadi mandiri). Dengan perkataan lain, pembelajaran adalah solusi tepat untuk pelaksanaan kurikulum 2006, dan bukan dengan kegiatan mengajar

Sebagaimana tergambar dalam prinsip-prinsip penyelenggaraan pendidikan yang dikemukakan Mardiatmaja (Sarkim, 1998: 128-129) bahwa pendidikan pada dasarnya mencerminkan keutuhan pendidikan manusia dan membantu agar manusia menjadi lebih manusiawi dengan tiga prinsip sebagai berikut :

(1) dalam proses pendidikan, pengembangan hati dan pikiran harus berjalan secara bersama-sama;

(2) peserta didik harus diberi kesempatan untuk berkenalan dengan nilai-nilai kemanusiaan yang abadi dan universal;

(3) dalam pendidikan harus ada kerjasama erat antara peserta didik dan pendidik, juga antara teori dan praktek.

Sebenarnya konsep di atas merupakan konsep humanizing human through educationt yang telah lama dikemukakan oleh banyak pakar pendidikan humanis sejak berabad-abad lalu. Inti dari teori tersebut sejalan dengan konsep tabularasa dikemukakan oleh John Locke yang beranggapan bahwa pendidikan adalah penentu masa depan seseorang sebab manusia dilahirkan bagaikan kertas putih yang masih kosong. Tulisan atas kertas putih yang kosong itulah yang menentukan baik buruknya manusia. Namun Schopenhauer mempunyai pendapat yang bertentangan dengan pendapat John Locke itu. Ia mengatakan bahwa sejak lahir manusia sudah membawa potensi dan bakat yang menentukan masa depannya sedangkan pendidikan sama sekali tidak mempunyai pengaruh terhadap seseorang bertentangan dengan Schopenhauer, melainkan lebih mengarah pada aliran konvergensi yang dianut oleh Al-Ghazali dan juga William Stern. Pandangan konvergensi tersebut mengemukakan bahwa manusia memang sejak lahir sudah membawa potensi dan bakat. Namun potensi dan bakat tersebut tidak akan berkembang dengan sendirinya secara maksimal tanpa dibantu dengan proses pendidikan. Intinya, pendidikan humanis dapat dipahami sebagai model pendidikan yang memuliakan manusia atas potensi-potensi kemanusiaan yang sudah ada dalam dirinya. Pada model pendidikan ini, manusia dipandang sebagai subyek yang otonom, sehingga pendidikan harus berpusat pada peserta didik dan bukan pada pendidik. Selama tujuan pendidikan adalah untuk mengenalkan peserta didik terhadap realitas yang ada di sekitarnya dan menyadarkan mereka akan proses dehumanisasi yang terjadi atasnya, maka peserta didik tidak lagi dijejali dengan hapalan teori melainkan dengan membawa mereka pada realitas itu sendiri, melalui integrasi antara teori dengan praktek. 


\section{Model Sekolah Ramah Anak.}

Sekolah merupakan salah satu komponen utama dalam kehidupan seorang anak selain keluarga dan lingkungan sekitar mereka. Secara umum sekolah adalah tempat dimana anak distimulasi untuk belajar di bawah pengawasan guru. Sekolah juga tempat yang signifikan bagi siswa dalam tahap perkembangannya dan merupakan sebuah lingkungan sosial yang berpengaruh bagi mereka. Selain itu sekolah harus pula menjadi tempat mengembangkan aspek kognitif, afektif dan psikomotor anak. Sekolah yang memenuhi kriteria tersebut disebut sebagai Sekolah Ramah Anak (SRA).

SRA, menurut UNICEF, menjamin pengadaan lingkungan yang aman, situasi emosi yang tentram, dan terbuka terhadap perkembangan psikologis anak. SRA juga didefinisikan oleh Shaeffer (1999) sebagai sekolah yang mengembangkan lingkungan belajar dimana anak-anak tidak sulit dan termotivasi untuk belajar. Selain itu, jajaran guru dan staf sekolah bersifat terbuka dan memperhatikan kesehatan serta keselamatan anak selama mereka di sekolah. Secara umum seluruh sistem sosial dan lembaga lain yang berkaitan langsung dengan anak-anak harus dilandasi oleh hak-hak anak yang tertuang dalam Konvensi Hak-Hak Anak. Terutama bagi sekolah dimana, seperti sudah disebutkan sebelumnya, merupakan tempat anak menghabiskan sebagian besar waktunya.

Paparan di atas memberikan gambaran mengenai pentingnya sebuah sekolah untuk menunjang kebutuhan anak dalam lingkungan sekolah. Lebih baik lagi apabila penyediaan lingkungan dan fasilitas dalam sebuah sekolah juga mengakomodir apa yang diinginkan anak pada sebuah sekolah. Dengan demikian diharapkan akan timbul kesinambungan antara pihak sekolah dan siswa yang akan menuju ke arah mutu pendidikan yang lebih baik. Sekolah Ramah Anak ini bersifat berkesinambungan dan diharapkan akan menimbulkan efek positif yang beruntun.

Ciri- ciri sekolah ramah anak dikemukakan Adman (2009:1) antara lain :

a. Sikap terhadap murid

1) perlakuan adil bagi murid laki perempuan, cerdas lemah, kaya miskin, cacat sehat, anak pejabat ataupun anak buruh

2) penerapan norma agama, social dan budaya setempat

3) kasih sayang kepada murid, member perhatian bagi mereka

4) saling menghormati hak-hak anak baik antar murid, antar tenaga kependidikan dan murid

b. Metode Pembelajaran 
1) Terjadi proses belajar sedemikian rupa sehingga siswa merasakan senang mengikuti pelajaran, tidak ada rasa takut, cemas dan was-was, siswa aktif dan kreatif serta tidak merasa rendah diri bersaing dengan teman lainnya

2) Terjadi proses belajar yang efektif dihasilkan oleh penerapan metode pembelajaran yang variatif dan inovatif

3) Proses belajar mengajar didukung oleh media ajar seperti buku pelajaran, alat peraga sehingga membantu daya serap murid

4) Guru sebagai pasilitator menerapkan proses belajar mengajar yang kooperatif, interaktif baik individu maupun kelompok.

5) Terjadi proses pembelajaran yang partisipatif. Murid lebih aktif, guru sebagai pasilitator mendorong dan mempasilitasi murid menemukan sendiri cara menjawab suatu persoalan.

6) Murid dilibatkan dalam berbagai aktifitas yang mengembangkan kemampuannya (learning by doing, praktek dll)

c. Penataan Kelas

1) Murid dilibatkan dalam penataan bangku, dekorasi dan ilustrasi yang menggambarkan ilmu pengetahuan

2) Murid dilibatkan dalam menentukan warna dinding, dekorasi sehingga murid menjadi betah di dalam kelas

3) Murid dilibatkan dalam memajangkan hasil karyanya, hasil ulangan sehingga artistic dan menarik.

4) Bangku dan kursi sebaiknya ukurannya disesuaikan

d. Lingkungan Sehat

1) Murid dilibatkan dalam mengungkapkan gagasannya dalam menciptakan sekolah

2) Tersedia air bersih, hygiene dan sanitasi, fasilitas kebersihan dan kesehatan

3) Fasilitas sanitasi seperti toilet, tempat cuci di sesuaikan dengan kebutuhan seusia anak, misalnya bak mandi tidak terlalu tinggi.

4) Di sekolah ditekankan pada peraturan yang mendukung kebersihan dan kesehatan. Kebijakan peraturan ini disepakati, dikontrol dan dilaksanakan oleh murid.

Ciri lain juga tentang sekolah ramah anak di kemukakan oleh EENET asia Newsletters : Edisi Simposium April 2006 sebagai berikut:

a. Inklusif secara proaktif

1) Secara proaktif mencari semua anak yang termarginalisasi dari pendidikan;

2) Mempromosikan dan membantu untuk memonitor hak-hak dan kesejahteraan semua anak di masyarakat;

3) Menghargai keberagaman dan memastikan kesetaraan kesempatan; 
4) Memberikan pendidikan yang bebas biaya dan wajib, murah dan aksesibel.

b. Efektif dan Berpusat Anak

1) Bertindak menurut kepentingan terbaik tiap anak;

2) Peduli kepada anak "seluruhnya": kesehatan, status gizi dan kesejahteraan;

3) Peduli tentang apa yang terjadi kepada anak sebelum mereka masuk sekolah dan setelah pulang dari sekolah;

4) Metode yang kreatif di dalam ruang kelas.

c. Sehat, Aman dan Protektife

1) Fasilitas toilet yang bersih;

2) Akses kepada air minum yang bersih;

3) Tidak ada hukum fisik atau ganguan;

4) Pencegahan HIV dan AIDS dan nondiskriminasi terhadap anak terinfeksi/tertular HIV dan AIDS.

d. Partisipasi Masyarakat

1) Terfokus pada keluarga:

a) Bekerja untuk memperkuat keluarga sebagai pemberi asuhan dan pendidik utama bagi anak;

b) Membantu anak, orang tua dan guru membangun hubungan harmonis dan kolaboratif.

2) Berbasis komunitas:

a) Mendorong kemitraan setempat dalam pendidikan;

b) Bertindak dalam dan dengan masyarakat untuk kepetingan anak.

e. Sistem Ramah terhadap Anak

1) Pengajaran yang sesuai dengan kebutuhan, kemampuan dan gaya belajar tiap anak;

2) Belajar aktif, koperatif dan demokratis;

3) Isi terstruktur dan materi dan sumber daya yang berkualitas baik;

4) Mengajar anak bagaimana belajar;

5) Melindungi anak dari pelecehan dan bahaya kekerasan.

\section{Pembelajaran dalam Dimensi Sekolah Ramah Anak}

\section{a. Contoh Sekolah Ramah Anak dan Ramah Lingkungan}

Seperti apa sih cara belajar di SRA? Mari kita meninjau ke Sekolah Dasar Negeri (SDN) Bantarjati 9 yang berada di Jalan Dalurung No. 20, BantarjatiBogor. Sekilas tampak biasa dari fisik bangunan, tapi ada yang luar biasa di sisi pendidikan. Ada apakah? Sejak tahun 1985 SDN 9 Bantarjati memproklamirkan diri sebagai Sekolah Ramah Anak dan Sekolah Ramah Lingkungan. Ini bukan 
hanya slogan karena tampak pada lingkungan SD Bantarjati 9 yang bersih nyaman dan cara belajar yang unik. Di sekitar lingkungan sekolah ditanami 150 jenis tanaman hias, 50 jenis tanaman budidaya, 50 jenis Tanaman Obat Keluarga (TOGA) dan jenis 50 tanaman dapur hidup. Satu persatu siswa harus menyebutkan jenis TOGA dan manfaatnya sambil berbaris sebelum masuk kelas.

Para siswa juga dibiasakan menyiram jamban setelah mengunakan WC, penghematan air dan listrik, membuang dan memilah sampah pada tempatnya yang telah disediakan. Sampah dedaunan dikumpulkan untuk untuk pembuatan pupuk kompos (organik). Dengarlah gemercik air dari air terjun buatan dengan kolam berisi ratusan ikan hias! Sungguh lingkungan sekolah yang asri dan nyaman. Asyiknya lagi, saat cuaca cerah para siswa diajak keluar kelas untuk mencari tempat yang nyaman. "Kami mengajak mereka untuk memandang gumpalan awan yang melayang dilangit. Kemudian seluruh siswa memperoleh kesempatan untuk menyampaikan imajinasi yang ada dalam pikirannya,"Ibu Yayah Komariah, Kepala Sekolah SDN Bantarjati 9 menjelaskan.

Di dalam kelas, ada kliping berita hasil pencarian siswa. Setelah dibacakan di depan kelas, kliping tersebut dipajang di ruang kelas. Siswa SDN 9 juga ramahramah lho. Mereka memang dibiasakan mengucapkan salam, berbicara positif dan komunikatif. Fasilitas lab komputer dan internet juga sudah tersedia di sini. Jadi, tak heran kalau segudang prestasi telah diraih oleh sekolah ini. Hebat!**

Memperhatikan contoh dan langkah yang dilakukan oleh SD Negeri 9 Bartarjati di atas juga memperhatikan beberapa model pembelajaran yang dapat digunakan sebagai alternative pembelajaran di sekolah ramah anak maka akan kita implementasikan dalam rencana pembelajaran.

Untuk memberikan gambaran tentang pembelajaran matematika dengan pendekatan penemuan terbimbing, berikut ini diberikan contoh-contoh rencana pelaksanaan pembelajaran sebagai berikut.

\section{b. Metode dan Model Pembelajaran}

Metode pembelajaran adalah cara yang dilakukan guru dalam membimbing peserta didik agar mencapai kompetensi yang ditetapkan. Metode pembelajaran yang bisa digunakan antara lain sebagai berikut.

1) Metode Bercerita

Metode bercerita adalah cara bertutur kata dan penyampaian cerita atau memberikan penjelasan kepada anak secara lisan.

2) Metode Bercakap-cakap

Metode bercakap-cakap berupa kegiatan bercakap-cakap atau bertanya jawab antara anak dengan guru atau antara anak dengan anak. Bercakap-cakap dapat dilaksanakan dalam bentuk (1) bercakap-cakap bebas, (2) bercakap-cakap 
menurut tema, dan (3) bercakap-cakap berdasarkan gambar seri. Dalam bercakap-cakap bebas kegiatan tidak terikat pada tema, tetapi pada kemampuan yang diajarkan. Bercakap-cakap menurut tema dilakukan berdasarkan tema tertentu. Bercakap-cakap berdasarkan gambar seri menggunakan gambar seri sebagai bahan pembicaraan.

3) Metode Tanya Jawab

Metode tanya jawab dilaksanakan dengan cara mengajukan pertanyaan tertentu kepada anak. Metode ini digunakan untuk: (1) mengetahui pengetahuan dan pengalaman yang telah dimiliki anak, (2) memberi kesempatan anak untuk bertanya, dan (3) mendorong keberanian anak untuk mengemukakan pendapat.

4) Metode Karyawisata

Metode karyawisata dilakukan dengan mengajak anak mengunjungi objekobjek yang sesuai dengan tema.

5) Metode Demonstrasi

Metode demonstrasi dilakukan dengan cara mempertunjukkan atau memperagakan suatu cara atau suatu keterampilan. Tujuannya agar anak memahami dan dapat melakukannya dengan benar, misalnya, mengupas buah, memotong rumput, menanam bunga, mencampur warna, meniup balon kemudian melepaskannya, menggosok gigi, mencuci tangan, dan lain-lain.

6) Metode Sosiodrama atau Bermain Peran

Metode sosiodrama adalah cara memberikan pengalaman kepada anak melalui bermain peran, yakni anak diminta memainkan peran tertentu dalam suatu permainan peran. Misalnya, bermain jual beli sayur-mayur, bermain menolong anak yang jatuh, bermain menyayangi keluarga, dan lain-lain.

7) Metode Eksperimen

Metode eksperimen adalah cara memberikan pengalaman kepada peserta didik dalam mengadakan percobaan terhadap sesuatu dan mengamati akibatnya. Misalnya, menanam tanaman yang mudah tumbuh (dengan biji cabe, tomat, kacang hijau; dengan batang singkong; dengan daun cocor bebek), dan lain-lain.

8) Metode Proyek

Metode proyek adalah metode yang memberikan kesempatan kepada anak untuk melakukan aktifitas belajar secara bertahap, dimana dari tahapan awal sampai tahapan akhir yang merupakan satu kesatuan rangkaian kegiatan. Metode ini menggunakan alam sekitar dan kegiatan sehari-hari yang sederhana untuk dilakukan oleh anak.

9) Metode Pemberian Tugas 
Metode pemberian tugas adalah metode yang digunakan untuk memberi kesempatan kepada peserta didik melaksanakan tugas yang disiapkan oleh guru.

\section{0) Metode Penemuan}

Metode penemuan adalah metode yang member kesempatan kepada anak untuk dapat menemukan sendiri tentang konsep yang dipelajarinya, baik secara murni maupun terbimbing.

11) Pembelajaran Berbasis masalah (PBL, Problem Based Learning) Kehidupan adalah identik dengan menghadapi masalah. Model pembelajaran ini melatih dan mengembangkan kemampuan untuk menyelesaikan masalah yang berorientasi pada masalah otentik dari kehidupan aktual siswa, untuk merangsang kemamuan berpikir tingkat tinggi. Kondisi yang tetap hatrus dipelihara adalah suasana kondusif, terbuka, negosiasi, demokratis, suasana nyaman dan menyenangkan agar siswa dap[at berpikir optimal. Indikator model pembelajaran ini adalah metakognitif, elaborasi (analisis), interpretasi, induksi, identifikasi, investigasi, eksplorasi, konjektur, sintesis, generalisasi, dan inkuiri.

\section{Simpulan}

Sekolah ramah anak menitikberatkan pada pentingnya sebuah sekolah untuk menunjang kebutuhan anak dalam lingkungan sekolah. Sekolah ramah anak dapat berjalan dengan baik apabila berbagai pihak terlibat berpartisipasi, yaitu guru-guru, staf sekolah, orangtua, lembaga masyarakat, dan tentunya anak yang bersekolah.

Sekolah ramah anak dapat diimplementasikan melalui pembelajaran yang berkualitas. Dengan demikian pembelajaran inovatif yang mampu membirikan layana kepada siswa guna berkembang potensinya merupakan keharusan dalam sekolah ramah anak. Pembelajaran yang inovatif tersebut sudah seharusnya memfasilitasi siswa mengembangkan potensinya dan membantunya mencapai tugas-tugas perkembangannya, sikap dan perilaku seorang pembimbing, menerima dan memahami kondisi siswa, mampu menciptakan iklim interaksi dengan anak yang harmonis. Dalam hal ini, siswa dilibatkan dalam berbagai aktivitas yang dapat mengembangkan kemampuannya (learning by doing). Siswa diberi kesempatan untuk menyampaikan gagasannya, memajangkan hasil karyanya diikutsertakan dalam pemeliharaan fasilitas sekolah. 


\section{DAFTAR PUSTAKA}

Depdiknas, (2006). Kurikulum Tingkat Satuan Pendidikan. Jakarta: Depdiknas.

EENET asia Newsletters : (2006). Edisi Simposium April 2006.

Moeslichatoen, R. (2004). Metode Pengajaran di Taman Kanak-Kanak. Jakarta : Rineka Cipta

Markaban. (2006). Model Pembelajaran Matematika dengan Pendekatan Penemuan Terbimbing.Yogyakarta : Pusat Pengembangan dan Penataran Guru Matematika

Peraturan Pemerintah Republik Indonesia Nomor 19 Tahun 2005 Tentang Standar Pendidikan Nasional.

Sumarmo, Utari (2001). Model Pembelajaran Matematika untuk Meningkatkan Kemampuan Tingkat Tinggi Siswa SD. Jurnal Penelitian Pendidikan UPI. I(33) : $1-13$

Suherman Eman. (2009). Model Belajar dan Pembelajaran Berorientasikan Kompetensi Siswa: Bandung : Universitas Pendidikan Indonesia

Sujiono, B. dan Yuliani Nurani. (2005). Pembelajaran Anak Usia Dini. Jakarta : Yayasan Citra Pendidikan Indonesia

Undang-undang RI No. 20 tahun 2003 Tentang Sistem Pendidikan Nasional. Jakarta : Restindo Media Tama

\section{BIODATA PENULIS}

Encep Sudirjo adalah dosen pada Universitas Pendidikan Indonesia dpk. UPI Kampus Cibiru Bandung. Penulis menyelesaikan pendidikan pada jenjang Magister (S-2) Pendidikan Anak Usia Dini pada Program Pascasarjana Universitas Negeri Jakarta. 